\title{
Effect of Hempseed (Cannabis sativa sp.) Inclusion to the Diet on Performance, Carcass and Antioxidative Activity in Japanese Quail (Coturnix coturnix japonica)
}

\author{
Yusuf Konca*, Behzat Cimen ${ }^{1}$, Hasan Yalcin², Mahmut Kaliber, Selma Buyukkilic Beyzi \\ Agricultural Faculty, Animal Science Department, Erciyes University, 38039 Kayseri-Turkey \\ ${ }^{I}$ Pharmasy Faculty, Erciyes University, 38039 Kayseri-Turkey \\ ${ }^{2}$ Engineering Faculty, Food Engineering Department, Erciyes University, 38039 Kayseri-Turkey
}

\begin{abstract}
This study was conducted to determine the effects of hempseed $(\mathrm{H})$ on performance, carcass traits, and antioxidant activity in Japanese quail (Coturnix coturnix japonica). A total of 192 quail with seven-days old were divided into four experimental groups with four replicates. The treatments were; i) Control diet (C, no hempseed); ii) $5 \%$ hempseed in diet (H5); iii) $10 \%$ hempseed in diet (H10); and iv) $20 \%$ hempseed in diet (H20). The body weight (BW) and feed intake (FI) of quail was determined at 7,21 and $42 \mathrm{~d}$ of age. At $42 \mathrm{~d}$ of age four quail were slaughtered and the carcass and internal organ traits were determined. Malondialdehyde (MDA), catalase (CAT), superoxide dismutase (SOD), glutathione peroxidase (GSH-Px), nitric oxide $(\mathrm{NO})$ and total protein were determined in the blood serum end of the experiment. The $\mathrm{BW}$ of the groups were not significant at 7 and $21 \mathrm{~d}$, however in the $20 \%$ hempseed group BW decreased at $42 \mathrm{~d}(p<0.05)$. The FI and feed conversion ratio were not significant among the treatment groups. The carcass, liver, intestine and heart weight and their percentage to carcass were significantly differ in treatment groups $(p<0.05)$. The serum MDA and NO decreased in hempseed addition $(p$ $<0.001)$. The serum SOD, CAT and GSH-Px were increased by hempseed supplementation $(p<0.001)$. In conclusion, hempseed supplementation to quail diets may not improve quail performance traits but increase antioxidant activity in blood.
\end{abstract}

Key words: hempseed, quail, performance, carcass, antioxidant activity

\section{Introduction}

The cannabis sativa is an annual plant and well known as an important source of food, dietary oil and medicine for thousands of years in many western and eastern countries (Callaway, 2004; de Padua et al., 1999). Hempseed both crushed and whole, remains an important grain in traditional Asiatic foods and medicines (Callaway, 2004). Industrial hemp with low levels $(<2 \mathrm{~g} / \mathrm{kg})$ of delta-9-tetrahydrocannabinoid (THC) has been permitted for cultivation in European Union countries with EU Council regulation 1782/2003 (2008). Also, EU commission has been working on regulations of hemps' THC levels and usage in different areas (Callaway, 2008). Hempseed contains about $30 \%$ oil and $25 \%$ protein, $34 \%$ carbohydrates, dietary fibre, vitamins and minerals (Callaway, 2004;

\footnotetext{
*Corresponding author: Yusuf Konca, Agricultural Faculty, Animal Science Department, Erciyes University, 38039 KayseriTurkey, Tel: +90-505-5056058700, Fax: +90-352-4376209, Email: yusufkonca@erciyes.edu.tr
}

Kriese et al., 2004). Hempseed oil is high in polyunsaturated fatty acids (PUFAs, about $80 \%$ ), and rich in two essential fatty acids such as linoleic acid (18:2 $\omega-6$, 55.48\%) and $\alpha$-linolenic acid (18:3 $\omega-3$ 21.51\%) (Bağci et al., 2003; Uluata and Ozdemir, 2012) which are important for optimal human health (Schwab et al., 2006). Also, linoleic and linolenic fatty acids in quail (Yalcin et al., 2012) and layer hens' (Gakhar et al., 2012; Goldberg et al., 2012; Silversides and Le Francois, 2005) diets may transfer to meat or egg via hempseed and hemp oil usage. In addition hempseed is rich in many essential amino acids, especially high levels of arginine and methi- onine and special peptides (Callaway, 2004; Tang et al., 2006). It is well known that antioxidant activities of peptides are closely related to amino acid composition and sequences of these amino acids and hempseeds' special protein types show potential of natural antioxidant agents (Gebrekidan, 2012). The consumption of foodstuffs rich in antioxidants provides protection against cancer and cardiovascular diseases (Parker et al., 2003). Uluata and Ozdemir (2012) and Chen et al. (2012) reported that hem- 
pseed can be utilized for the production of formulations containing phytochemicals with significant antioxidant properties and health benefits and hempseed addition could increase the shelf life of the products as well. Additionally, it is reported that hempseed's cannabidiols have antimicrobial, immunomodulatory, antioxidative, antihypertensive and mineral binding properties (Korhonen and Pihlanto, 2003). The development of bioactive protein peptides of hempseed may contribute to new economic opportunities for increased value-added utilization of hemp ( $\mathrm{Lu}$ et al., 2010).

Cells generate small amounts of free radicals or reactive oxygen species (ROS) while performing their normal metabolic functions. Although low levels of ROS are essential in many biochemical processes, high levels of ROS may damage cells and tissue macromolecules, that is, lipids, proteins, carbohydrates and deoxyribonucleic acid (DNA) (Mates et al., 1999; Tang et al., 2006). The tocopherols, phenolic compounds and carotenoids present in vegetable oils are used against the oxidation reaction (Chen et al., 2012; Ramadan et al., 2003; Uluata and Ozdemir, 2012). Due to all these properties, in the past, hemp oil and seed had been used as a medical plant to treat some diseases (de Padua et al., 1999).

It is reported that hempseed is an excellent source of nutrition. Not only traditional Chinese medicine but also recent modern human clinical trials agree that hempseed has health promoting properties which is supported by results from nutritional analyses of the seed, oil and seed meal (Callaway, 2004). Recently, to be protected from some illnesses, natural antioxidants have attracted great attention from consumers due to their reliable properties compared to synthetic ones. As a result of healthy food production strategy, use of natural antioxidants in diets is alleviating. The aim of the present study was to determine the effects of hempseed on performance, carcass and oxidative activity parameters in the blood of Japanese quail.

\section{Material and Methods}

\section{Animal and diets}

A total of (192 unsexed seven-day-old Japanese quail chicks (Coturnix coturnix japonica) were individually weighed, wing banded and distributed into 4 treatment groups with 4 replicates and 12 chicks per cage. Each cage was furnished with a heater, two wateriers and feeders. The rearing cage dimensions were $50 \times 90 \times 20 \mathrm{~cm}$ (wide, length, height). Replicates were designated as the experimental units, and randomized with respect to the dietary treatments. The diet treatments were as follows; 1) Basal diet, hempseed not included in diet (control=C); 2) $5 \%$ hempseed inclusion (H5); 3) 10\% hempseed inclusion (H10); 4) 20\% hempseed inclusion (H20). The experimental diets were offered to quail for $5 \mathrm{wk}$. Maizesoybean based diets were utilized and all formulated on similar levels of nutrient composition. The hempseed was bought from a local seed shop. All diets' compositions were prepared according to NRC (1994) recommendations. The compositions of hempseed and experimental diets used in this study were given in Table 1 and Table 2, respectively.

\section{Measurements}

The individual body weights (BW) of birds and feed intake (FI) for each subgroup were measured at $7^{\text {th }}, 21^{\text {st }}$ and $42^{\text {nd }} \mathrm{d}$ of age. Feed conversion ratio (FCR; FI/body weight gain, $\mathrm{g} / \mathrm{g}$ ) of groups were calculated for 7 to 21 , 21 to 42 , and 7 to $42 \mathrm{~d}$. Feed and water were offered as ad libitum. Animals were exposed to 24-h light during experiment. Mortality was recorded daily and was taken into consideration to calculate FI and FCR. For carcass evaluation 16 birds ( 8 males and 8 females, total 64 samples) in each group were randomly selected at $42 \mathrm{~d}$ of age and slaughtered. Their feathers were plucked, and the carcasses were eviscerated by hand. The small intestine, large intestine, and gizzard were removed, the contents were expelled. The carcass, liver, heart, proventriculus, gizzard, and empty intestine (duodenum + ileum + jejunum + cecum + colon) were recorded individually and part yields were obtained as part weight: carcass weight X 100. Cold carcass weights were recorded after the carcasses had been stored at $4^{\circ} \mathrm{C}$ for $18 \mathrm{~h}$.

For biochemical analysis, blood samples were obtained from venipuncture of the neck of the aforesaid animals ( 8 males and 8 females in each subgroups, total 64 samples). The blood samples were then kept on ice and transferred to the laboratory where they were centrifuged at $740 \times \mathrm{g}$ for $10 \mathrm{~min}$ to remove the serums. The serums then were stored at $-70^{\circ} \mathrm{C}$ until the analysis. Malondialdehyde (MDA), catalase (CAT), superoxide dismutase (SOD), glutathione peroxidase (GSH-Px), nitric oxide (NO) and total protein were determined in the blood serum according to methods below.

\section{Analytical Methods}

\section{The fatty acid (FA) composition analysis}

Fatty acid compositions of the hempseed samples were 
determined according to the Agilent application catalogue. For the analysis, the oil of samples were extracted with ether and stored in eppendorf tubes from which the air was removed and replaced by nitrogen. The samples were stored at $-60^{\circ} \mathrm{C}$ until the analysis. The oil $(100 \mathrm{mg})$ was saponified with $100 \mu \mathrm{L} 2 \mathrm{~N} \mathrm{KOH}$, and $3 \mathrm{~mL}$ hexane was added to the mixture. The mixture was vigorously shaken with a vortex for $1 \mathrm{~min}$, and then centrifuged at $2900 \mathrm{~g}$ for $5 \mathrm{~min}$. FA compositions were analyzed by a GC (Agilent 6890, USA) equipped with a Flame Ionization Detector and a $100 \mathrm{~m} \times 0.25 \mathrm{~mm}$ ID HP-88 column. Injector temperature was $250^{\circ} \mathrm{C}$. The oven temperature was kept at $103^{\circ} \mathrm{C}$ for $1 \mathrm{~min}$, then programmed from 103 to $170^{\circ} \mathrm{C}$ at $6.5^{\circ} \mathrm{C} / \mathrm{min}$, from 170 to $215^{\circ} \mathrm{C}$ for $12 \mathrm{~min}$ at $2.75^{\circ} \mathrm{C} /$ min, finally, $230^{\circ} \mathrm{C}$ for $5 \mathrm{~min}$. The carrier gas was helium with a flow rate of $2 \mathrm{~mL} / \mathrm{min}$; split rate was $1 / 50$. FA was identified by comparison of retention times to known standards. The results were expressed as g fatty acid / 100 $\mathrm{g}$ total fatty acids $(\%)$.

\section{The determination of malondialdehyde (MDA)}

The malondialdehyde levels, as an index of lipid peroxidation was determined by thiobarbituric acid reaction according to Yoshoiko et al. (1979). The principle of the method depends on the measurement of the pink color produced by interaction of thiobarbituric acid with malondialdehyde. The pink color absorbances are measured at $532 \mathrm{~nm}$ and the MDA levels are expressed as $\mu \mathrm{mol} / \mathrm{L}$.

\section{The determination of Nitric oxide (NO)}

Plasma nitrite and nitrate determinations are increasingly being used in clinical chemistry as a marker for the activity of nitric oxide synthase and the production of nitric oxide radicals. We performed an enzymatic methodology based on the reduction of nitrate to nitrite by nitrate reductase (E.C.1.6.6.2) from Aspergillus species, in the presence of $\beta$-NADPH. The concomitant oxidation of coenzyme was monitored by the decrease in absorbance at $340 \mathrm{~nm}$. The method of standard addition was used to minimize the effect of interfering substances from serum. This spectrophotometric method was used to measure nitrate present in serum. Nitrite and nitrate present in serum were in proportion to total nitrogen oxides $\left(\mathrm{NO}_{\mathrm{x}}\right)$ determined by the method. Nitrate was measured as nitrite after enzymatic conversion by nitrate reductase (E.C.1.6. 6.2). Total nitrite concentration of serum was measured by using the Griess reaction (Bories et al., 1995; Moshage et al., 1995). Total nitrite concentration as NO levels was expressed as $\mu \mathrm{mol} / \mathrm{L}$.

\section{The determination of catalase activity (CAT)}

The CAT activity was measured by the method of Yasmineh (1995). This method is based on the disappearance of $\mathrm{H}_{2} \mathrm{O}_{2}$ at $240 \mathrm{~nm}$ in a reaction medium containing $\mathrm{H}_{2} \mathrm{O}_{2}$, potassium phosphate buffer ( $\mathrm{pH}$ 7.0). Catalase activity was obtained from molar absorption coefficient of $\mathrm{H}_{2} \mathrm{O}_{2}$ and the absorbance change per minute. The CAT activity was expressed as $\mathrm{ku} / \mathrm{L}$.

\section{The determination of superoxide dismutase activity (SOD)}

The SOD activity was measured by the method described originally by Sun et al. (1988). This assay for superoxide dismutase (SOD, EC 1.15.1.1) activity involves inhibition of nitro-blue tetrazolium reduction, with xanthine-xanthine oxidase used as a superoxide generator. The enzyme activity is expressed as units/mg protein.

\section{The determination of glutathione peroxidase (GSH- Px) activity}

Glutathione peroxidase activity was measured with the method of Mishra (1990) which was modified from Paglia and Valentine (1967). The reaction contained glutathione, glutathione reductase, sodium azide, and NADPH. NADPH disappearance was monitored at $340 \mathrm{~nm}$ using a spectrophotometer. The enzyme activity is expressed as oxidized $\mathrm{nmol} \mathrm{NADPH} / \mathrm{min} / \mathrm{mg}$ protein (unit/mg protein).

\section{The determination of protein}

Protein concentrations in the serum were determined using a Lowry assay (Lowry et al., 1951). This method is based on the reaction of cupric ions with peptide bonds under alkaline conditions. Concentrations were calculated from a standard curve constructed using bovine serum albumin and protein levels are expressed as $\mathrm{mg} / \mathrm{ml}$.

\section{Statistical analysis}

Data were analyzed by using One-way Anova under General Linear Models of SPSS computer software (SPSS (1998). The model included hempseed level of diets. The means were separated using Duncan's multiple range tests. The results of statistical analysis were shown as mean values and standard error of means (SEM) in the tables. Statistical significance was considered at $p<0.05$.

\section{Results}

The hempseed nutrient and fatty acids composition are presented in Table 1. The hempseed's dry matter, crude 
Table 1. Analysed nutrient and fatty acid composition of hempseed

\begin{tabular}{cc}
\hline \hline Item & Ratio, \% \\
\hline Dry matter & 95.11 \\
Crude protein & 21.05 \\
Crude oil & 31.45 \\
Crude ash & 8.80 \\
\hline Fatty acid composition of hemseed oil* & \\
Palmitic acid, C16:0 & 6.67 \\
Stearic acid, C18:0 & 2.87 \\
Oleic acid, C18:1 $(\omega-9)$ & 11.50 \\
Linoleic, C18:2 $(\omega-6)$ & 52.51 \\
Linolenic, C18:3 $(\omega-3)$ & 23.24 \\
Arachidic acid, C20:0 & 0.65 \\
Gadoleic acid, C 20:1 & 0.57 \\
Behenic acid, C 22:0 & 0.25 \\
$\omega-6 / \omega-3$ & 2.26 \\
PUFA & 87.9 \\
\hline
\end{tabular}

$* \mathrm{~g}$ fatty acid / $100 \mathrm{~g}$ total fatty acids (\%).

protein, fat and ash were 95.11, 21.05, 31.45 and 8.8\% respectively. The fatty acids of hempseed oil were found as linoleic acid $52.51 \%$, linolenic acid $23.24 \%$, $\omega-6 / \omega-3$ ratio 2.26 and PUFA $87.9 \%$. The effects of hempseed on body weight (BW), feed intake (FI) and feed conversion ratio (FCR) values were shown in Table 3. There were no differences statistically among the treatment groups in terms of FI, FCR and BW on d 7 and d 21 during the experimental period $(p>0.05)$. However, on $\mathrm{d} 42$, inclusion of $20 \%$ hempseed decreased the BW of quail $(p<$ $0.05)$.

Effect of hempseed inclusion on carcass and intestinal organ traits and their relative incidence were given in Table 4. The carcass and heart weights of the H10 group were higher than those of the other treatment groups $(p<$ 0.05 ). The liver and intestine weight in the $\mathrm{C}$ group was higher than those of the others $(p<0.01)$ but carcass yield was lower than all hempseed supplemented groups $(p<$ $0.05)$. The gizzard weight and the gizzard and heart relative incidence were not influenced by the treatments. The intestine weight and relative incidence of $\mathrm{H} 20$ groups was lower than those of the other groups $(p<0.01)$. The heart weight and relative incidence were not influenced by sex. The carcass, liver, gizzard, intestine weights and liver, gizzard and intestine relative incidence were lower in male quail $(p<0.05$ and $p<0.01)$. Hempseed level and sex interactions were not influenced by the treatments. In general $20 \%$ hempseed inclusion decreased the carcass and internal organ weight and relative incidence.

The effects of hempseed included diets on serum mal-

Table 2. Diets feedstuff and nutrient composition

\begin{tabular}{|c|c|c|c|c|}
\hline \multirow{2}{*}{ Feedstuffs } & \multicolumn{4}{|c|}{ Diets, hempseed level, \% } \\
\hline & $0(\mathrm{C})$ & $5(\mathrm{H} 5)$ & $10(\mathrm{H} 10)$ & $20(\mathrm{H} 20)$ \\
\hline Corn & 391.40 & 400.00 & 400.00 & 385.11 \\
\hline Wheat & 100.00 & 55.60 & 22.58 & 0.00 \\
\hline Soybean meal & 353.94 & 345.41 & 337.33 & 339.20 \\
\hline Sunflower meal & 100.00 & 93.82 & 84.84 & 27.23 \\
\hline Vegetable oil & 25.76 & 26.00 & 26.00 & 18.37 \\
\hline Sodium chloride & 3.46 & 3.53 & 3.59 & 3.64 \\
\hline Di-calcium phosphate & 6.94 & 7.42 & 7.90 & 9.03 \\
\hline Limestone & 13.48 & 13.37 & 13.26 & 13.20 \\
\hline Vitamin-mineral premix $^{1}$ & 2.50 & 2.50 & 2.50 & 2.50 \\
\hline DL-Methionine & 1.20 & 1.09 & 0.80 & 0.83 \\
\hline L-Lysine & 1.32 & 1.26 & 1.20 & 0.89 \\
\hline Hempseed & 0.00 & 50.00 & 100.00 & 200.00 \\
\hline \multicolumn{5}{|l|}{ Calculated nutrient composition $^{2}$} \\
\hline Dry matter, \% & 88.29 & 88.74 & 88.11 & 88.69 \\
\hline Crude protein, $\%$ & 24.39 & 24.48 & 24.52 & 24.60 \\
\hline Calcium, \% & 0.80 & 0.80 & 0.80 & 0.80 \\
\hline Available phosphorus, \% & 0.30 & 0.30 & 0.30 & 0.30 \\
\hline Lysine, $\%$ & 1.30 & 1.30 & 1.30 & 1.30 \\
\hline Methionine, \% & 0.50 & 0.50 & 0.50 & 0.50 \\
\hline Metabolizable energy, $\mathrm{kcal} / \mathrm{kg}$ & 2860.30 & 2865.10 & 2889.00 & 2899.60 \\
\hline
\end{tabular}

${ }^{1}$ Vitamin-mineral premix per kilogram of the diet, Vitamin A, 15,000 IU; Vitamin D3 $2000 \mathrm{IU}$; Vitamin E, $40.0 \mathrm{mg}$; Vitamin K, 5.0 mg; Vitamin B1 (thiamine), $3.0 \mathrm{mg}$; Vitamin B2 (riboflavin), $6.0 \mathrm{mg}$; Vitamin B6, $5.0 \mathrm{mg}$; Vitamin B12, $0.03 \mathrm{mg}$; Niacin, $30.0 \mathrm{mg}$; Biotin, 0.1 $\mathrm{mg}$; Calcium D-pantothenate, $12 \mathrm{mg}$; Folic acid, $1.0 \mathrm{mg}$, Choline chloride, $400 \mathrm{mg}$, Manganese, $80.0 \mathrm{mg}$; Iron, $35.0 \mathrm{mg}$; Zinc, $50.0 \mathrm{mg}$; Copper, $5.0 \mathrm{mg}$; Iodine $2.0 \mathrm{mg}$; Cobalt, $0.4 \mathrm{mg}$; Selenium, $0.15 \mathrm{mg}$ assures. ${ }^{2}$ Nutrient composition of diets calculated according to NRC (1994) nutrient values of corn, wheat, soybean, sunflower meal and vegetable oil. 
Table 3. Effects of treatments on the body weight (BW), feed intake (FI) and feed conversion ratio (FCR) in Japanese quail

\begin{tabular}{|c|c|c|c|c|c|c|}
\hline \multicolumn{7}{|c|}{ Treatments } \\
\hline Day & $\mathrm{C}$ & $\mathrm{H} 5$ & $\mathrm{H} 10$ & $\mathrm{H} 20$ & SEM & $\mathrm{P}$ \\
\hline \multicolumn{7}{|c|}{ Body weight, g } \\
\hline 7 & 21.26 & 22.34 & 21.75 & 22.58 & 0.51 & NS \\
\hline 21 & 110.91 & 114.60 & 114.22 & 115.21 & 2.39 & NS \\
\hline 42 & $183.62^{\mathrm{a}}$ & $175.34^{\mathrm{ab}}$ & $183.40^{\mathrm{a}}$ & $168.50^{\mathrm{b}}$ & 3.94 & $*$ \\
\hline \multicolumn{7}{|c|}{ Feed intake, g/day } \\
\hline 7 to 21 & 8.24 & 7.92 & 8.84 & 7.41 & 0.67 & NS \\
\hline 21 to 42 & 25.58 & 23.77 & 27.33 & 22.82 & 1.51 & NS \\
\hline 7 to 42 & 18.64 & 17.43 & 19.93 & 16.63 & 1.26 & NS \\
\hline \multicolumn{7}{|c|}{ Feed conversion ratio, g FI/g BWG } \\
\hline 7 to 21 & 1.19 & 1.33 & 1.34 & 1.26 & 0.57 & NS \\
\hline 21 to 42 & 5.80 & 8.19 & 6.10 & 9.83 & 0.95 & NS \\
\hline 7 to 42 & 2.88 & 3.53 & 2.98 & 3.81 & 0.08 & NS \\
\hline
\end{tabular}

${ }^{\mathrm{a}-\mathrm{c}}$ Values with different superscript in a row differ significantly ${ }^{*} p<0.05$. C, H5, H10, H20; hempseed ratio in diet as $0,5,1020 \%$ respectively; SEM: standard error of means. NS: non significant.

Table 4. Effect of hempseed $(\mathrm{H})$ in quail diet on carcass and intestinal organ traits

\begin{tabular}{|c|c|c|c|c|c|c|c|c|c|c|}
\hline & \multicolumn{5}{|c|}{ Absolute weight, $\mathrm{g}$} & \multicolumn{5}{|c|}{$\begin{array}{l}\text { Relative incidence, } \% \\
\end{array}$} \\
\hline & Carcass & Liver & Gizzard & Intestine & Heart & Carcass & Liver & Gizzard & Intestine & Heart \\
\hline \multicolumn{11}{|c|}{ Treatment } \\
\hline $\mathrm{C}$ & $125.6^{\mathrm{b}}$ & $4.19^{\mathrm{a}}$ & 3.97 & $9.16^{\mathrm{a}}$ & $1.54^{\mathrm{b}}$ & $67.08^{\mathrm{b}}$ & $3.33^{\mathrm{a}}$ & 3.15 & $7.27^{\mathrm{a}}$ & 1.22 \\
\hline H5 & $124.9^{\mathrm{b}}$ & $3.55^{\mathrm{b}}$ & 3.74 & $7.40^{\mathrm{b}}$ & $1.46^{\mathrm{b}}$ & $70.85^{\mathrm{a}}$ & $2.84^{\mathrm{b}}$ & 3.00 & $5.91^{\mathrm{b}}$ & 1.17 \\
\hline $\mathrm{H} 10$ & $133.9^{\mathrm{a}}$ & $3.86^{\mathrm{ab}}$ & 3.87 & $7.68^{b}$ & $1.74^{\mathrm{a}}$ & $70.60^{\mathrm{a}}$ & $2.89^{\mathrm{b}}$ & 2.89 & $5.72^{\mathrm{bc}}$ & 1.29 \\
\hline $\mathrm{H} 20$ & $122.5^{\mathrm{b}}$ & $3.16^{\mathrm{b}}$ & 3.71 & $6.14^{\mathrm{c}}$ & $1.51^{\mathrm{b}}$ & $72.00^{\mathrm{a}}$ & $2.59^{\mathrm{b}}$ & 3.03 & $5.05^{\mathrm{c}}$ & 1.23 \\
\hline \multicolumn{11}{|l|}{ Sex } \\
\hline Male & $124.0^{\mathrm{b}}$ & $2.86^{\mathrm{b}}$ & $3.41^{\mathrm{b}}$ & $6.28^{\mathrm{b}}$ & 1.55 & $72.91^{\mathrm{a}}$ & $2.31^{\mathrm{b}}$ & $2.75^{\mathrm{b}}$ & $5.07^{\mathrm{b}}$ & 1.25 \\
\hline Female & $129.5^{\mathrm{a}}$ & $4.52^{\mathrm{a}}$ & $4.23^{\mathrm{a}}$ & $8.91^{\mathrm{a}}$ & 1.57 & $67.36^{\mathrm{b}}$ & $3.51^{\mathrm{a}}$ & $3.27^{\mathrm{a}}$ & $6.90^{\mathrm{a}}$ & 1.21 \\
\hline \multicolumn{11}{|c|}{ Interactions } \\
\hline $\mathrm{C}^{*} \mathrm{M}$ & 124.9 & 3.12 & 3.62 & 7.24 & 1.50 & 71.19 & 2.51 & 2.91 & 5.82 & 1.20 \\
\hline $\mathrm{C}^{*} \mathrm{~F}$ & 126.4 & 5.26 & 4.31 & 11.07 & 1.58 & 62.97 & 4.15 & 3.38 & 8.72 & 1.24 \\
\hline $\mathrm{H} 5 * \mathrm{M}$ & 118.7 & 3.00 & 3.24 & 6.23 & 1.43 & 72.68 & 2.52 & 2.74 & 5.23 & 1.20 \\
\hline $\mathrm{H} 5 * \mathrm{~F}$ & 131.0 & 4.10 & 4.23 & 8.56 & 1.50 & 69.01 & 3.15 & 3.25 & 6.60 & 1.14 \\
\hline $\mathrm{H} 10 * \mathrm{M}$ & 129.5 & 2.84 & 3.56 & 6.38 & 1.74 & 74.07 & 2.21 & 2.76 & 4.96 & 1.34 \\
\hline $\mathrm{H} 10 * \mathrm{~F}$ & 138.3 & 4.88 & 4.17 & 8.98 & 1.74 & 67.13 & 3.58 & 3.02 & 6.47 & 1.24 \\
\hline $\mathrm{H} 20 * \mathrm{M}$ & 122.9 & 2.48 & 3.20 & 5.25 & 1.53 & 73.69 & 2.02 & 2.60 & 4.29 & 1.25 \\
\hline $\mathrm{H} 20 * \mathrm{~F}$ & 122.2 & 3.85 & 4.23 & 7.03 & 1.48 & 70.32 & 3.16 & 3.45 & 5.82 & 1.22 \\
\hline \multicolumn{11}{|l|}{ SEM } \\
\hline $\mathrm{H}$ & 2.62 & 0.18 & 0.16 & 0.40 & 0.06 & 1.08 & 0.14 & 0.11 & 0.29 & 0.04 \\
\hline Sex & 1.86 & 0.13 & 0.11 & 0.29 & 0.05 & 0.76 & 0.10 & 0.08 & 0.21 & 0.03 \\
\hline$H^{*} \operatorname{sex}$ & 3.71 & 0.25 & 0.22 & 0.57 & 0.09 & 1.53 & 0.20 & 0.15 & 0.42 & 0.05 \\
\hline \multicolumn{11}{|c|}{ Probability } \\
\hline $\mathrm{H}$ & $*$ & $* *$ & NS & $* *$ & $*$ & $*$ & $* *$ & NS & $* *$ & NS \\
\hline Sex & $*$ & $* *$ & $* *$ & $* *$ & NS & $* *$ & $* *$ & $* *$ & $* *$ & NS \\
\hline$H^{*} \operatorname{sex}$ & NS & NS & NS & NS & NS & NS & NS & NS & NS & NS \\
\hline
\end{tabular}

${ }^{\mathrm{a}-\mathrm{c}}$ Values with different superscript in a column differ significantly ${ }^{*} p<0.05,{ }^{*} p<0.01 ; \mathrm{C}, \mathrm{H} 5,1020$ : hempseed ratio in diet as $5,1020 \%$; SEM: standard error of means; NS: non significant.

ondialdehyde (MDA), superoxide dismutase (SOD), catalase (CAT), glutathione peroxidase (GSH-Px) and nitric oxide (NO) activity showed in Table 5 and Figs. 1, 2, 3, 4 and 5 . The serum protein levels were not affected by the hempseed addition into quail diets $(p>0.05)$. The serum MDA and NO levels were decreased by hempseed addi- tion into quail diets $(p>0.05)$. In this study, all hempseed supplemented groups serum SOD, CAT and GSH-Px levels were increased compared to control group $(p<0.001)$. The serum MDA, SOD, CAT and GSH-Px values in male quail were higher than female, however in female serum NO level was higher than males $(p<0.01)$. Interactions 
Table 5. Effects of hempseed inclusion to quail diets on serum malondialdehyde (MDA), superoxide dismutase (SOD), catalase (CAT), glutathione peroxidase activity (GSH-Px) and nitric oxide (NO)

\begin{tabular}{|c|c|c|c|c|c|c|}
\hline Groups & $\begin{array}{c}\text { Protein } \\
(\mathrm{g} / \mathrm{dl})\end{array}$ & $\begin{array}{c}\text { MDA } \\
(\mu \mathrm{mol} / \mathrm{L})\end{array}$ & $\begin{array}{c}\mathrm{NO} \\
(\mu \mathrm{mol} / \mathrm{L})\end{array}$ & $\begin{array}{c}\text { SOD } \\
\text { (U/mg protein) }\end{array}$ & $\begin{array}{c}\text { CAT } \\
(\mathrm{kU} / \mathrm{L})\end{array}$ & $\begin{array}{c}\text { GSH-Px } \\
\text { (U/mg protein) }\end{array}$ \\
\hline $\mathrm{C}$ & 3.74 & $2.86^{\mathrm{a}}$ & $18.95^{\mathrm{a}}$ & $0.294^{\mathrm{d}}$ & $19.07^{d}$ & $13.74^{\mathrm{d}}$ \\
\hline $\mathrm{H} 5$ & 3.75 & $2.62^{\mathrm{b}}$ & $18.34^{\mathrm{b}}$ & $0.309^{\mathrm{c}}$ & $19.12^{\mathrm{c}}$ & $15.46^{\mathrm{c}}$ \\
\hline $\mathrm{H} 10$ & 3.75 & $2.60^{\mathrm{b}}$ & $17.63^{c}$ & $0.316^{\mathrm{b}}$ & $19.19^{\mathrm{b}}$ & $16.02^{\mathrm{b}}$ \\
\hline $\mathrm{H} 20$ & 3.75 & $2.49^{\mathrm{c}}$ & $17.46^{\mathrm{c}}$ & $0.328^{\mathrm{a}}$ & $19.34^{\mathrm{a}}$ & $17.13^{\mathrm{a}}$ \\
\hline \multicolumn{7}{|l|}{ Sex } \\
\hline Male & $3.7^{b}$ & $2.15^{\mathrm{a}}$ & $17.68^{b}$ & $0.32^{\mathrm{a}}$ & $19.23^{\mathrm{a}}$ & $15.92^{\mathrm{a}}$ \\
\hline Female & $3.8^{\mathrm{a}}$ & $2.13^{b}$ & $18.51^{\mathrm{a}}$ & $0.31^{\mathrm{b}}$ & $19.12^{\mathrm{b}}$ & $15.41^{\mathrm{b}}$ \\
\hline \multicolumn{7}{|l|}{ SEM } \\
\hline Hempseed level & 0.02 & 0.02 & 0.12 & 0.002 & 0.016 & 0.18 \\
\hline Sex & 0.003 & 0.01 & 0.02 & 0.0004 & 0.004 & 0.22 \\
\hline \multicolumn{7}{|l|}{ Probability } \\
\hline Hempseed level & NS & $* *$ & $* * *$ & $* * *$ & $* * *$ & $* * *$ \\
\hline Sex & $* *$ & $* *$ & $* *$ & $* *$ & $* *$ & $* *$ \\
\hline Interaction & NS & NS & $* *$ & $*$ & $*$ & NS \\
\hline
\end{tabular}

${ }^{\mathrm{a}-\mathrm{c}}$ Values with different superscript in a columns are differ significantly; ${ }^{* * *} p<0.001 ;{ }^{* *} p<0.01,{ }^{*} p<0.05 . \mathrm{C}, \mathrm{H} 5, \mathrm{H} 10, \mathrm{H} 20$ : hempseed ratio in diet as 0, 5, $1020 \%$ respectively; SEM: standard error of means; NS: non significant.

(hempseed and sex) affected serum NO $(p<0.01)$, SOD and CAT values $(p<0.01)$.

\section{Discussion}

The compositional analysis showed that hempseed contained $21.05 \%$ protein and $31.45 \%$ oil. These results were similar to the results obtained by Callaway (2004) and House et al. (2010). Also the fatty acids of hempseed oil were found $\mathrm{C} 18: 2,52.51 \%$; $\mathrm{C} 18: 323.24 \%$ and $\omega-6 / \omega-3$ ratio 2.26. Similar fatty acid content and $\omega-6 / \omega-3$ ratio were reported by Callaway (2004) and Uluata and Ozdemir (2012). The inclusion of hempseed to layer (Gakhar et al., 2012), quail (Yalcin et al., 2012) and feedlot (Gibb et al., 2005) diets showed an increase in high ratio $\omega-6$ and $\omega-3$ fatty acids.

Hempseed supplementation to quail diet did not affect BW on d 7 and d 21 but inclusion of $20 \%$ hempseed decreased the BW of quail on $\mathrm{d} 42(p<0.05)$. The FI and FCR values were not affected by the treatments. Silversides and Lefrancois (2005) and Gakhar et al. (2012) showed that including up to $20 \%$ hempseed meal in diets did not significantly influence the BW of laying hens. Also, similar results were obtained by Gibb et al. (2005) who reported that 0,9 and $14 \%$ hempseed inclusion to feedlot cattle did not change BW, BWG and FI of steers. However, in contrast to our results, Khan et al. (2010) found that $20 \%$ hempseed inclusion to diets increased BW of broilers. However, as a processed product hempseed cake inclusion to broiler diets did not affect perfor- mance traits (Eriksson and Wall, 2012). Analysis results showed that hempseed contained high percentages of crude ash $(8.80 \%$, Table 1) and cellulose (House et al., 2010). This ratio is considerably high when compared to some traditional feeds such as corn, wheat and soybean meal. High crude ash and cellulose levels in diets may cause lower BW due to decreasing of energy and digestibility of feeds. On the other hand, it is reported that hempseed has high quality protein content and amino acid composition (Callaway, 2004). However, due to addition of hempseed some amino acid content may be excessively increased in diet, and imbalance of amino acid ratios in diet may have an antagonistic effect and lower amino acid bioavailability. Another reason of lower BW in H20 group may also be high related to THC content increase in the diet (Callaway, 2004). Unfortunately, there are only a few hempseed inclusion experiments in the literature to discuss and compare with our results.

Hempseed and its by-products have been used from ancient times until today as a medicinal plant (de Padua et al., 1999). Today, there are still many unknowns about hempseed and its oil's nutritional value and effects when used in animal and human diets. The development and characterization of the bioactive contents in novel foods are required to provide scientific evidence to improve their quality and nutritional value (Yu et al., 2005). The present study was designed to evaluate the inclusion of hempseed on performance and serum lipid antioxidant properties of Japanese quail. Hempseed contains 30\% oil which is high in linoleic (LA) and alpha-linolenic acids 
(ALA) (Callaway, 2004; Uluata and Ozdemir, 2012). The LA and ALA are necessary in body as essential fatty acids and protect cell uniformity in the diet for healthy individuals (Goldberg et al., 2012).

In the H10 group the carcass and heart weights were higher than those of other groups. However, in the C group the liver weight was higher than 5 and $20 \% \mathrm{H}$ groups and intestinal weight were higher than those of the other groups. When considered the relative incidence of carcass in the C group's carcass ratio was lower and liver and intestinal incidence was higher than those of the hempseed supplemented groups. The gizzard weights and incidences were not influenced by the treatments. Male quail carcass and internal organ traits without carcass incidence were lower than those of females. Khan et al. (2010) reported that $20 \%$ hempseed in broiler rations did not affect positively dressing percentage at $42 \mathrm{~d}$. Callaway (2004) reported that hempseed has some beneficial effect on health in human and animals therefore it is hypothesized its inclusion may increase quail performance traits. However, in this study superior results were not observed in performance traits but increased carcass percentage.

The serum protein levels were not affected by the hempseed addition into quail diets. In this study, protein levels of all diets were adjusted at similar levels. On the other hand, hempseed protein level (21.2\%, Table 1) was similar with the experimental quail diets (24\%), therefore serum protein levels were not significantly affected by the hempseed inclusion. There are no enough studies results for comparison of our results with others. However, Karimi and Hayatghaibi (2006) reported that hempseed in rat diet after $20 \mathrm{~d}$ caused an increase in blood protein levels compared to blood protein level at first day of the experiment. Although, their experiment lack of control diet, there is a comparison with first and last day of the experiment to evaluate rat blood component.

The MDA, a carbonile group produced during lipid peroxidation, is used widely in determining oxidative stress and formed as an end product of lipid peroxidation (Sumida et al. (1989). Lipid peroxidation is a chain reaction providing a continuous supply of free radicals as it involves the oxidation of polyunsaturated fatty acids contributes to the loss of cellular functions through the inactivation of membrane enzymes and even of cytoplasmic proteins and consequences cell damage. On molecular level of lipid peroxidation, the importance of oxidative membrane damage is twofold (Stark, 2005). In the present study, the serum MDA levels were decreased by hempseed addition into quail diets. This may show that hempseed inclusion to quail diets has a positive effect against to lipid peroxidation in the serum of Japanese quail. On the other hand hempseed contains some special protein types and amino acids (Lu et al., 2010) and high ratio of $\omega-3$ and $\omega-6$ fatty acids which may protect the integrity of the cell membrane (Uluata and Ozdemir, 2012). Hu et al., (2008) reported that serum MDA levels were decreased in test rats those fed by diets with hemp seed oil at the end of 90-day trial period compared with control groups of contained soybean oil and the normal diet. Also, it is reported that extract of cinnamon (Faix et al., 2009; Ciftci et al., 2010), rosemary (Yesilbag et al., 2011), oregano (Botsoglou et al., 2002) decreased MDA levels in broilers and quails (Bulbul et al., 2012).

NO is produced at the cellular level from L-arginine catalyzed by nitric oxide synthase, a very important signaling molecule (Nathan, 1992). NO is a diffusible free radical that plays many roles as an effector molecule in diverse biological systems including vasodilatation, neuronal messenger, immunological response, antimicrobial and antitumor activities (Beckman and Koppenol, 1996; Balakrishnan et al., 2009). However, NO participates in several cell processes as a highly reactive free radical (Moncada et al., 1991). NO in the body is oxidized within seconds; in the presence of oxygen and the oxidation endproducts of NO can oxidize cell lipids (Hassanpour et al., 2009) consequently, cell damage occurs. In the current study, hempseed inclusion to diets caused a linear decrease in the serum NO levels. The control group serum NO level was higher than all other groups $(p<0.001)$. These results revealed that the inclusion of hempseed to quail diets exhibited well in NO scavenging activity. The present study shows that hempseed inclusion to diet may potent nitric oxide scavenging activity. Similar results with green tea were obtained by Hassanpour et al. (2010) which showed green tea supplementation to broiler diets reduced NO metabolites as free radical group.

The SOD, GSH-Px, and CAT are antioxidative enzymes act as the first step of antioxidant defense and protection cells against damage of free radical groups (Tang et al., 2003). In the body, increase of these antioxidant enzymes enhances in scavenging activity for oxygen free radicals. In this study, all hempseed supplemented groups' the serum SOD, CAT and GSH-Px levels were increased compared to control group. Furthermore, when hempseed inclusion rate were increased, in a linear increase in the level of serum SOD, CAT and GSH-Px was observed $(p<0.001)$. These findings showed that hempseed inclusion increased total blood antioxidant enzyme capacity. Hu et al. (2008) 
found that serum SOD and GSH-Px levels increased significantly at the end of 90-day feeding with hempseed oil. Hempseed and its oil contain some phenolic compounds, n3 and n6 fatty acids (Callaway, 2004), special peptides and protein types (Lu et al., 2010) and they have protection ability against harmful effects of ROS in the body (Gebrekidan, 2012; Uluata and Ozdemir, 2012). In different experiment results showed that vegetable oils such as rosemary and garlic (Ancsin et al., 2009) and cinnamon oil (Ciftci et al., 2010) in broilers and essential oil's mixture of different plants (Bozkurt et al., 2012) increased GSH-Px levels in layers.

Taken together, these results showed that the hempseed inclusion at 5, 10 and $15 \%$ levels to Japanese quail diet improved antioxidant status of animals. Because, hempseed has special fatty acids composition (Uluata and Ozdemir, 2012), phenolic compounds (Chen et al., 2012; Uluata and Ozdemir, 2012), special proteins and amino acids (Gebrekidan, 2012), antimicrobial, immunomodulatory, antioxidative, antihypertensive and mineral binding properties (Korhonen and Pihlanto, 2003). In addition to Yu et al. (2005) reported that hempseed oil has better oxygen radical absorbing capacity than many plant oils. Therefore it has unique material to protect against ROS and protect cell membrane integrity. The researchers claimed that findings are significant for the discovery and development of natural antioxidants from hemp by-products (Callaway, 2004; Chen et al., 2012; Korhonen and Pihlanto, 2003; Uluata and Ozdemir, 2012; Yu et al., 2005). Results of the our study are confirming the findings of Callaway (2004) who reported that hempseed oil is a functional food for animal and humans and for animal feeding long-standing utility as an important food resource.

\section{Conclusion}

In conclusion, according to our results, up to $10 \%$ hempseed may use in quail diet without negative effect on performance and carcass traits and hempseed inclusion may increase carcass yield. In this experiment hempseed inclusion did not cause any significant change in serum protein levels, but caused decrease in serum MDA and NO levels and increase in serum SOD, CAT and GSH-Px as antioxidant parameters. These parameters revealed that hempseed have good potential as a natural antioxidant material for health improvement and disease prevention. In addition, hempseed ingredients as natural antioxidant source may contribute to longer duration of shelf life of animal products. There is no enough experiment on effect of hempseed inclusion in animal diets and its nutritive and antioxidant efficacy in animals (Botsoglou et al., 2002). Further experiments are needed to determine the effects of hempseed in poultry feeding.

\section{Acknowledgments}

The authors gratefully acknowledge the technical assistance of H. H. Uzkulekci and A. E. Sekmen from the Agricultural Faculty, Animal Science Department, Erciyes University. This research was supported by the Erciyes University Scientific Research Project Directorate.

\section{References}

1. Ancsin, Z. Erdélyi, M., and Mézes, M. (2009) Effect of rosemary and garlic oil supplementation on glutathione redox system of broiler chickens. Acta Bio. Szegedi. 11, 19-21.

2. Bağci, E. Bruehl, L. Aitzetmuller, K., and Altan, Y. (2003) A chemotaxonomic approach to the fatty acid and tocochromanol content of Cannabis sativa L. (Cannabaceae). Turk. J. Bot. 27, 141-147.

3. Balakrishnan, N. Panda, A. B. Raj, N. R. Shrivastava, A., and Prathani, R. (2009) The Evaluation of Nitric Oxide Scavenging Activity of Acalypha Indica Linn Root. Asian J. Res. Chem. 2, 148-150.

4. Beckman, J. S. and Koppenol, W. H. (1996) Nitric oxide, superoxide, and peroxynitrite: the good, the bad, and the ugly. Am. J. Physiol. Cell. Physiol. 271, 1424-1437.

5. Bories, P. N. and Bories, C. (1995) Nitrate determination in biological fluids by an enzymatic one-step assay with nitrate reductase. Clin. Chem. 41, 904-907.

6. Botsoglou, N. A., Florou-Paneri, P., Christaki, E., Fleouris, D. J., and Spais, A. B. (2002) Effects of dietary essential oil on performance of chickens and on iron-induced lipid oxidation of breast, thigh and abdominal fat tissues. Br. Poult. Sci. 43, 223-230.

7. Bozkurt, M., Tokuşoğlu, Ö., Küçükyılmaz, K., Akşit, H., Çabuk, M., Çatlı, A. U., Seyrek, K., and Çınar, M. (2012) Effects of dietary mannan oligosaccharide and herbal blend supplementation on performance and oxidative stability of eggs and liver in laying hens. Ital. J. Anim. Sci. 11, 223-229.

8. Bulbul, A., Bulbul, T., Biricik, H., Yesilbag, D., and Gezen, S. S. (2012) Effects of various levels of rosemary and oregano volatile oil mixture on oxidative stress parameters in quails. Afr. J. Biotech. 7, 1800-1805.

9. Callaway, J. C. (2004) Hempseed as a nutritional resource: an overview. Euphytica. 140, 65-72.

10. Callaway, J. C. (2008) A more reliable evaluation of hemp THC levels is necessary and possible. J. Ind. Hemp. 13, 117144.

11. Chen, T., He, J., Zhang, J., Li, X., Zhang, H., Hao, J., and Li, L. (2012) The isolation and identification of two compounds with predominant radical scavenging activity in hempseed 
(seed of Cannabis sativa L.). Food Chem. 134, 1030-1037.

12. Ciftci, M., Simsek, U. G., Yuce, A., Yilmaz, O., and Dalkilic, B. (2010) Effects of dietary antibiotic and cinnamon oil supplementation on antioxidant enzyme activities, cholesterol levels and fatty acid compositions of serum and meat in broiler chickens. Acta Vet. Brno. 79, 33-40.

13. Council Regulation (EC) No 1124/2008. (2008) of 12 November 2008 amending Regulations (EC) No 795/2004, (EC) No 796/2004 and (EC) No (1973/2004, as regards the hemp varieties eligible for direct payments under Council Regulation (EC) No 1782/2003. Official Journal of the European Union. 14.11.2008. L 303/7.

14. de Padua, L. S., Bunyaprafatsara, N., and Lemmens, R. H. M. J. (1999) Plant Resources of South-East Asia. Medicinal and Poisonous Plants. Backhuys Publishers, Leiden. p. 167-175.

15. Eriksson, M. and Wall, H. (2012) Hempseed cake in organic broiler diets. Anim. Feed Sci. Tech. 171, 205-213.

16. Faix, Š., Faixová, Z., Plachá, I., and Koppel, J. (2009) Effect of cinnamomum zeylanicum essential oil on antioxidative status in broiler chickens. Acta Vet. Brno, 78, 411-417.

17. Gakhar, N., Goldberg, E., Jing, M., Gibson, R., and House, J. D. (2012) Effect of feeding hempseed and hempseed oil on laying hen performance and egg yolk fatty acid content: Evidence of their safety and efficacy for laying hen diets. Poult. Sci. 91, 701-711.

18. Gebrekidan, B. (2012) Antioxidant activity of hempseed protein-derived peptides obtained by hydrolysis with proteinase K. Master's Thesis. Department of Human Nutritional Sciences, University of Manitoba, Winnipeg, Manitoba, p. 102.

19. Gibb, D. J., Shah, M. A., Mir, P. S., and McAllister, T. A. (2005) Effect of full-fat hemp seed on performance and tissue fatty acids of feedlot cattle. Can. J. Anim. Sci. 85, 223-230.

20. Goldberg, E. M., Gakhar, N., Ryland, D., Aliani, M., Gibson, R. A., and House, J. D. (2012) Fatty acid profile and sensory characteristics of table eggs from laying hens fed hempseed and hempseed oil. J. Food Sci. 77, 153-159.

21. Hassanpour, H., Zamani Moghaddam, A. K., Yazdani, A., and Cheraghchi, B. M. (2010) Evaluation of intestinal morphology and nitric oxide metabolites in broiler chickens supplemented by green tea. Comp. Clin. Pathol. 19, 43-47.

22. Hassanpour, H., Nikbakht, B. G. H., and Mohammad, Z. A. (2009) Different gene expression of the constitutive nitric oxide synthase (NOS-3) in bull epididymis and vas deferens. Comp. Clin. Pathol. 18, 7-11.

23. House, J. D., Neufeld, J., and Leeson, G. (2010) Evaluating the quality of protein from hemp seed (Cannabis sativa L.) products through the use of the protein digestibility-corrected amino acid score method. J. Food Chem. 58, 11801-807.

24. Hu, X. F., Li, Y., Wang, J., Song, X., and Li, Y. (2008) Study on safety assessment and antioxidant function in serum of hempseed oil. Chin. J. Food Hygen. Abst. p. 5.

25. Karimi, I. and Hayatghaibi, H. (2006) Effect of Cannabis sativa $L$. seed (Hempseed) on serum lipid and protein profiles of rat. Pakistan J. Nutr. 5, 585-588.

26. Khan, R. U., Durrani, F. R., Chand, N., and Anwar, H. (2010) Influence of feed supplementation with Cannabis sativa on quality of broilers carcass. Pakistan Vet. J. 30, 34-38.

27. Korhonen, H. and Pihlanto, A. (2003) Food-derived bioactive peptides-opportunities for designing future foods. Cur. Pharm. Design, 9, 297-308.

28. Kriese, U., Schumann, E., Weber, W. E., Beyer, M., Brühl, L., and Matthäus, B. (2004) Oil content, tocopherol composition and fatty acid patterns of the seeds of 51 Cannabis sativa $\mathrm{L}$. Genotypes. Euphytica. 137, 339-351.

29. Lowry, O. H., Rosebrough, N. J., Farr, A. L., and Randall, R. J. (1951) Protein measurement with the Folin-Phenol reagents. J. Biol. Chem. 193, 265-275.

30. Lu, R. R., Qian, P., Sun, Z., Zhou, X. H., Chen, T. P., He, J. F., Zhang, H., and Wu, J. (2010) Hempseed protein derived antioxidative peptides, Purification, identification and protection from hydrogen peroxide-induced apoptosis in PC12 cells. Food Chem. 123, 1210-1218.

31. Mates, J. M., Perez-Gomez, C., Nunez, I., and Castro, D. E. (1999) Antioxidant enzymes in human diseases. Clinic. Biochem. 32, 595-603.

32. Mishra, O. P., Papadapoulos, D. M., and Wagerle, L. C. (1990) Antioxidant enzymes in the brain of newborn piglets during ischemia followed by reperfusion. Neurosci. 35, 211-215.

33. Moncada, S., Palmer, R. M. J., and Higgs, E. A. (1991) Nitric oxide: physiology, pathophysiology, and pharmacology. Pharm. Rev. 43, 109-142.

34. Moshage, H., Kok, B., Huizenga, J. R., and Jansen, P. L. M. (1995) Nitrite and nitrate determinations in plasma: A Critical Evaluation. Clin. Chem. 41, 892-896.

35. Nathan, C. (1992) Nitric oxide as a secretory product of mammalian cells. Feder Am. Soc. Exp. Bio. 6, 3051-3064.

36. NRC. (National Research Council) (1994) Nutrient requirements of Ring-Necked Pheasants, Japanese Quail, and Bobwhite Quail, Nutrient requirements of poultry (9th rev. ed). National Academy Press, Washington DC., USA. p. 45.

37. Paglia, D. E. and Valentina, W. N. (1967) Studies on quantitative and qualitative characterization of erythrocyte glutathione peroxidase. J. Lab. Clin. Med. 70, 158-169.

38. Parker, T. D., Adams, D. A., Zhou, K., Harris, M., and Yu, L. (2003) Fatty acid composition and oxidative stability of coldpressed edible seed oils. J. Food Sci. 68, 1240-1243.

39. Ramadan, M. F., Lothar, W., Kroh, W., and Jörg, T. M. (2003) Radical scavenging activity of black cumin (Nigella sativa L.) coriander (Coriandrum sativum L.) and niger (Guizotia abyssinica Cass.) crude seed oils and oil fractions. J. Agric. Food Chem. 51, 6961-6969.

40. Schwab, U. S., Callaway, J. C., Erkkila, A. T., Gynther, J., Uusitupa, M. I., and Javinen, T. (2006) Effects of hempseed and flaxseed oils on the profile of serum lipids, serum total and lipoprotein lipid concentrations and haemostatic factors. Eu. J. Nutr., 45, 470-477.

41. Silversides, F. G. and Lefrancois, M. R. (2005) The effect of feeding hempseed meal to laying hens. Br. Poult. Sci. 46, 231235.

42. SPSS. (1988) SPSS for Windows. Base System User's Guide, Release 9.05. SPSS Inc., Chicago.

43. Stark, G. (2005) Functional consequences of oxidative mem- 
brane damage. J. Membr. Biol. 205, 1-16.

44. Sumida, S. K., Tanaka, K. K., and Akadomo, F. N. (1989) Exercise-induced lipid peroxidation and leakage of enzyme before and after vitamin E supplementation. Int. J. Biochem. 21, 835-838.

45. Sun, Y., Oberley, L. W., and Li, Y. (1988) A simple method for clinical assay of superoxide dismutase. Clin. Chem. 34, 497500.

46. Tang, C. H., Wang, X. S., and Yang, X. Q. (2003) Enzymatic hydrolysis of hemp (Cannabis sativa L.) protein isolate by various proteases and antioxidant properties of the resulting hydrolysates. Food Chem. 114, 1484-1490.

47. Tang, C. H., Ten, Z., Wang, X. S., and Yang, X. Q. (2006) Physicochemical and functional properties of hemp (Cannabis sativa L.) protein isolate. J. Agric. Food Chem. 54, 89458950.

48. Uluata, S. and Ozdemir, N. (2012) Antioxidant activities and oxidative stabilities of some unconventional oilseeds. J. Am. Oil Chem. Soc. 89, 551-559.

49. Yalcin, H., Durmuscelebi, F., and Konca, Y. (2012) Effects of cannabis sativa on fatty acid composition of quail (Coturnix coturnix japonica) meats and eggs. Kiel Food Science Symposium, Germany 22-23 May 2012, Abs. p. 54.

50. Yasmineh, W. G., Kaur, T. P., Blazar, B. R., and Theologides, A. (1995) Serum catalase as marker of graft-vs-host disease in allogeneic bone marrow transplant recipients: pilot study. Clin. Chem. 41, 1574-1580.

51. Yesilbag, D., Eren, M., Agel, H., Kovanlikaya, A., and Balci, F. (2011) Effects of dietary rosemary, rosemary volatile oil and vitamin $\mathrm{E}$ on broiler performance, meat quality and serum SOD activity. Br. Poult. Sci. 52, 472-482.

52. Yoshoiko, T., Kawada, K., and Shimada, T. (1979) Lipid peroxidation in maternal and cord blood and protective mechanism against activated-oxygen toxicity in the blood. Am. $J$. Obst. Gynec. 135, 372-376.

53. Yu, L. L., Zhou, K. K., and Parry, J. (2005) Antioxidant properties of cold-pressed black caraway, carrot, cranberry, and hempseed oils. Food Chem. 91, 723-729.

(Received 2013.12.8/Revised 2014.2.4/Accepted 2014.2.8) 